\title{
Dual Effect of Glycine on NMDA-Induced Neurotoxicity in Rat Cortical Cultures
}

\author{
Dennis McNamara and Raymond Dingledine \\ Department of Pharmacology, University of North Carolina School of Medicine, Chapel Hill, North Carolina 27599
}

To examine the roles of glycine in neurotoxicity caused by NMDA, primary rat cortical cultures were exposed to 100$300 \mu \mathrm{M}$ NMDA plus glycine $(0-3000 \mu \mathrm{M})$ or other glycine analogs in a simple saline solution, and toxicity was assessed by the amount of lactate dehydrogenase (LDH) released from the cultures. NMDA-induced neurotoxicity was abolished by $100 \mu \mathrm{M}$ D-2-amino-5-phosphonovaleric acid (D-APV), phencyclidine $\left(\mathrm{IC}_{50}, 4.1 \mu \mathrm{M}\right)$, and $\mathrm{Mg}\left(\mathrm{IC}_{50}, 7.5 \mathrm{mM}\right)$, or by reducing [Ca]。 to $0.1 \mathrm{mM}$. NMDA-induced neurotoxicity could also be abolished by 7-chlorokynurenic acid $\left(\mathrm{IC}_{50}, 8.6 \mu \mathrm{M}\right)$, suggesting the presence of residual glycine in the culture medium (confirmed by high-performance liquid chromatography measurement). Moreover, in the presence of $30 \mu \mathrm{M} 7$-chlorokynurenic acid, glycine, D-serine, D-alanine, $\beta$-fluoro-D-alanine, and 1-aminocyclopropanecarboxylic acid could restore the neurotoxic action of NMDA, and their relative potencies and relative efficacies were the same as measured in electrophysiological assays in Xenopus oocytes or cultured neurons.

The addition of $>100 \mu \mathrm{M}$ glycine doubled the excitotoxic effect of NMDA. The potency of glycine was low $\left(E C_{50}, 27\right.$ $\mu \mathrm{M})$, and this effect was not due to a direct action on the NMDA receptor. The above-mentioned agonists were unable to substitute for glycine, even at high concentrations ( $1 \mathrm{~mm}$ ). On the other hand, $\beta$-alanine, taurine, and GABA (1 $\mathrm{mm})$ did potentiate NMDA neurotoxicity, and strychnine $\left(\mathrm{IC}_{50}, 550 \mathrm{nM}\right)$ could greatly reduce neurotoxicity in the presence of $1 \mathrm{~mm}$ glycine plus $300 \mu \mathrm{M}$ NMDA. In addition, replacement of $67 \%$ of the bath chloride by methanesulfonate, which should limit chloride entry through amino acid-receptor channels, prevented the potentiation of neurotoxicity by glycine.

These data are consistent with a requirement for glycine in NMDA neurotoxicity. They also suggest that the rise in cytoplasmic chloride concentration that follows activation of the "inhibitory" glycine (and GABA) receptors potentiates NMDA-induced neurotoxicity, perhaps by causing neuronal swelling or by diverting energy stores for chloride transport that would otherwise be used to clear cytosolic calcium. These findings emphasize a metabolic coupling between the NMDA receptor and inhibitory amino acid receptors.

Received May 10, 1990; revised Aug. 2, 1990; accepted Aug. 20, 1990.

We thank Dan Mooney for contributing the low-calcium experiments. This work was supported by NIH Grants NS17771 and NS23804 and by a gift from the Bristol-Myers Squibb Company.

Correspondence should be addressed to Raymond Dingledine, Department of Pharmacology, University of North Carolina, Chapel Hill, NC 27599.

Copyright (c) 1990 Society for Neuroscience $0270-6474 / 90 / 123970-07 \$ 03.00 / 0$
The likely contribution of excessive NMDA-receptor activation to the neuropathologies associated with repeated seizures (Siejö and Weiloch, 1986), ischemic or hypoxic brain damage (Simon et al., 1984; Gill et al., 1987; Ozyurt et al., 1988), and perhaps neurodegeneration associated with Huntington's chorea (Martin and Gusella, 1986) and aging (Moroni et al., 1984) is recognized. An in vitro culture model has been developed to study the cellular basis for and pharmacological control of excitotoxicity (Rothman, 1983). The majority of neurons in mature cortical or hippocampal cultures that have been exposed to NMDA or glutamate, or made briefly hypoxic, die over the succeding 24 hr (Rothman, 1983; Choi et al., 1987; Fransden and Schousboe, 1987; Goldberg et al., 1987). A variety of competitive and noncompetitive NMDA-receptor antagonists prevent much of the neurotoxicity caused by hypoxia, or by brief exposure to NMDA or glutamate in culture (Goldberg et al., 1987; Rothman et al., 1987; Choi et al., 1988), which provides strong evidence for the involvement of NMDA receptors in the culture model of excitotoxicity. Of special importance was the observation that post hoc administration of NMDA-receptor antagonists effected partial protection both in vivo (e.g., Gill et al., 1987) and in culture (Choi et al., 1988). The possibility that NMDA-receptor blockers might be useful in decreasing brain damage caused by ischemia, hypoxia, or traumatic injury has therefore become of great interest.

The discovery of glycine as a positive modulator of NMDA receptors (Johnson and Ascher, 1987) identifies an additional potential target for the development of anti-ischemic drugs. The pharmacological properties of the glycine site, as assessed in voltage-clamp assays of NMDA-induced ionic currents in cultured neurons or frog oocytes injected with rat brain mRNA, are now fairly well understood. For example, the rank order for agonist potency at the glycine site expressed in oocytes is 1 -aminocyclopropanecarboxylic acid $(\mathrm{ACC})>$ glycine $>\mathrm{D}$-serine $>$ D-alanine $>\beta$-fluoro-D-alanine $>R$ - $(+)$ cycloserine $>$ I-serine $>$ I-alanine (McBain et al., 1989), and the glycine site is blocked competitively by several kynurenine and quinoxaline derivatives, including 7-chlorokynurenic acid (Kemp et al., 1988; Kleckner and Dingledine, 1989). The demonstration that glycine appears to be required for NMDA-receptor activation, both in mRNA-injected frog oocytes (Kleckner and Dingledine, 1988; McBain et al., 1989) and in cultured hippocampal neurons (Huettner, 1989; Lester et al., 1989; Benveniste et al., 1990) suggests that blockers of the glycine recognition site might be as efficacious as NMDA blockers of excitotoxicity. The potential role of the glycine recognition site in NMDA-receptor-mediated neurotoxicity is thus of some importance. The culture system provides a good opportunity to explore the role of glycine receptors in NMDA-receptor-mediated neurotoxicity. 
We report here that glycine potentiates and 7-chlorokynurenic acid abolishes NMDA-induced toxicity. The glycine site on the NMDA receptor is, however, already saturated by ambient glycine. The potentiation by glycine is shared by other inhibitory amino acids and is due to an action on the strychnine-sensitive glycine receptor.

Some of these results were presented to the Society for Neuroscience (McNamara and Dingledinc, 1988, 1989).

\section{Materials and Methods}

Tissue culture. Cerebral cortices were removed from Sprague-Dawley rat embryos on the nineteenth day of gestation. The olfactory bulb and meninges were removed, and cortices were minced and incubated in $0.1 \%$ trypsin at $37^{\circ} \mathrm{C}$ for $20 \mathrm{~min}$. Digestion due to residual enzyme was halted by addition of a mixture of $5 \%$ fetal calf serum plus $5 \%$ heatinactivated horse serum (FCHS) in Eagle's minimum essential medium (MEM). Tissue was then rinsed twice with Hank's balanced salt solution (HBSS) lacking $\mathrm{Ca}^{2+}$ and $\mathrm{Mg}^{2+}$ but supplemented with 10 mM HEPES. Cells were dissociated by trituration. The resulting suspension was then diluted in a plating medium consisting of $10 \%$ FCHS in MEM, 2 mM L-glutamine, $1 \mathrm{~mm}$ sodium pyruvate, sodium bicarbonate $(36.5 \mathrm{mM}$ total), and glucose ( $25 \mathrm{~mm}$ total). Cells were plated at 0.11 brains per $35-\mathrm{mm}$ well of 6 well plates and maintained in a humidified incubator at $37^{\circ} \mathrm{C}$ and $8 \% \mathrm{CO}_{2}$.

On the fourth day after plating, serum was diluted by $1 / 2$ by addition of chemically defined medium (CDM). This is a growth medium containing, in Dulbecco's MEM:Ham's F12 (3:1), bovine serum albumin $(6.67 \mu \mathrm{M})$, dexamethasone $(26.0 \mathrm{nM}), \beta$-estradiol $(1.0 \mathrm{pM})$, insulin $(0.833$ pM), progesterone (20.0 nM), putrescine $(1.0 \mathrm{nM})$, sodium selenite $(30.0$ $\mathrm{nM})$, transferrin $(1.25 \mu \mathrm{M})$, and tri-iodothreonine $(310 \mathrm{nM})$. Prior to feeding, this medium was conditioned by incubation for 4-6 hr on a monolayer of glial cells, prepared by a method similar to that described above but from rats of postnatal age 5-10 d, and maintained in $10 \%$ FCHS. Subsequent feedings on days 7 and 9 or 10 involved removing approximately $1 / 2$ of the medium from the cells and replacing with glialconditioned CDM. In some experiments, cultures were treated with 10 $30 \mu \mathrm{M}$ cytosine arabinoside on day $4-11$ to retard division of the glial cell population.

NMDA exposure. On day 11 , a freshly made saline solution was used to rinse cells and to expose them to excitotoxic amino acids. The usual exposure solution differed from HBSS in that it contained no phenol red and only $14.3 \mathrm{~mm} \mathrm{NaHCO}$. This solution was made of reagentgrade salts in double-distilled water and glassware that had been baked at $300^{\circ} \mathrm{C}$ for $4 \mathrm{hr}$ to reduce glycine. Amino acid stocks and exposure solutions were also made up in this saline.

Rinse and exposure solutions containing varying concentrations of amino acids and antagonists were kept at $37^{\circ} \mathrm{C}$ prior to application to the cells. All were applied gently with a syringe or micropipette. Cells were rinsed 3 times in saline, each rinse remaining on the cells for 5 $\mathrm{min}$ in the $37^{\circ} \mathrm{C}$ incubator. Cells were then exposed to NMDA plus glycine or analogs for 5 or $10 \mathrm{~min}$ (exposure time was consistent within an experiment) at $37^{\circ} \mathrm{C}$, after which time, the exposure solution was replaced with CDM in MEM lacking sodium pyruvate but containing $100 \mu \mathrm{M}$ DL-APV. DL-APV was included to prevent further activation of NMDA receptors by residual NMDA or other agonists released by injured cells. To produce maximum injury, cultures were exposed to $100-300 \mu \mathrm{M}$ NMDA plus 100-300 $\mu \mathrm{M}$ glycine for $1 \mathrm{hr}$ (Fransden and Schousboe, 1987). After the 5-10-min or 1-hr exposure period, cells were incubated for a further 18-24 hr to allow manifestation of injury. Samples of the medium were then collected, and the cells from each well were scraped from the plate for measurements of lactate dehydrogenase (LDH) released and total tissue $\mathrm{LDH}$, respectively.

$L D H$ assay. Portions of each sample were assayed for LDH activity by the method of Koh and Choi (1987). Samples were added to $\beta$-NADH $(100 \mu \mathrm{M})$ in $0.1 \mathrm{M} \mathrm{KH} \mathrm{KO}_{4}$ buffer $(\mathrm{pH}, 7.5)$. Sodium pyruvate was then added to $767 \mu \mathrm{M}$, and the absorbance at $340 \mathrm{~nm}\left(A_{340}\right)$ was monitored spectrophotometrically. LDH activity in the sample was inferred from the rate of change of $A_{340}$. LDH activity was expressed as a percentage of the amount released following a 1-hr exposure to high NMDA and glycine concentrations, which was considered to be maximum release (Fransden and Schousboe, 1987). No extra LDH activity was released during the 5- or 10-min period of exposure to high concentrations of NMDA and glycine. The percentage of total LDH activity available that could be released into the medium by $1-\mathrm{hr}$ exposure to high concentrations of NMDA and glycine was calculated as the amount released during the postexposure incubation divided by the total LDH content of the dish.

Materials. Tissue culture media were obtained from Gibco, and sera from Hyclone. NMDA, D-APV, and DL-APV were obtained from Cambridge Research Biochemicals. Glycine, ACC, D-alanine, and D-serine were obtained from Pierce Chemical Company, $\beta$-alanine from Aldrich Chemical Company, $\beta$-fluoro-D-alanine from Merck Sharp and Dohme Research Labs, and $\beta$-NADH from Boehringer Mannheim. 7-Chlorokynurenic acid was purchased from Tocris. All other chemicals were obtained from Sigma Chemical Company.

\section{Results}

\section{NMDA-induced neurotoxicity}

As previously reported for L-glutamate (Choi, 1987; Finkbeiner and Stevens, 1988) and NMDA (Frandsen and Schousboe, 1987; Patel et al., 1990), exposure of rat cortical cultures to 100-300 $\mu \mathrm{M}$ NMDA for $1 \mathrm{hr}$ produced visually obvious swelling and granulation of neurons, followed by degeneration of a proportion of neurons over the succeeding 18-24 hr. To quantify this phenomenon, we measured the fraction of total LDH contained within the culture dish that was released into the medium 18$24 \mathrm{hr}$ after the initial exposure (Koh and Choi, 1987). Following a 1-hr exposure to NMDA (100-300 $\mu \mathrm{M})$ plus glycine (100-300 $\mu \mathrm{M}), 30.5 \pm 1.1 \%$ of the total $\mathrm{LDH}$ content in the culture dish was released into the medium $(n=88)$, whereas during a 5 - or 10-min control period without NMDA or glycine, only $5.6 \pm$ $0.3 \%$ was released $(n=88)$. All measurements of NMDA-induced LDH release were therefore scaled between these 2 values, determined separately in each experiment. (In the absence of excitotoxins, the baseline release of $\mathrm{LDH}$ over a $5-10-\mathrm{min}$ period was essentially the same as with a $1-\mathrm{hr}$ incubation.) The main objective of this study was to examine the roles of glycine in NMDA-induced neurotoxicity; accordingly, the period of exposure to NMDA was $10 \mathrm{~min}$ or less so that cell injury (and release of endogenous glycine) would be minimal during the exposure period. In contrast to most previous studies (Choi et al., 1987, 1988; Fransden and Schousboe, 1987; Favaron et al., 1988; Finkbeiner and Stevens, 1988; Patel et al., 1990), DL-APV $(100 \mu \mathrm{M})$ was added to the culture medium after the transient exposure to NMDA in order to eliminate additional neurotoxic effects of residual NMDA or glutamate that would be released from injured neurons in the postincubation period (Hartley and Choi, 1989; Shalaby et al., 1989). Thus, the activation of NMDA receptors was confined in all experiments to the 5-10-min exposure period.

Under these conditions, $10 \mathrm{~min}$ exposure to NMDA (plus $300 \mu \mathrm{M}$ glycine) produced a concentration-dependent release of LDH that reached a maximum of about $60 \%$ of the total releasable pool of $\mathrm{LDH}$ (Fig. $1 A$ ). The $\mathrm{EC}_{50}$ of NMDA was 360 $\mu \mathrm{M}$ [95\% confidence interval (CI), 330-400 $\mu \mathrm{M} ; n=7]$, higher than that found in previous studies under other conditions (Koh et al., 1986; Fransden and Schousboe, 1987; Finkbeiner and Stevens, 1988; Patel et al., 1990). The low NMDA potency was not due to a large proportion of NADPH-diaphorase $(+)$ neurons, which are selectively resistant to NMDA-receptor-mediated neurotoxicity (Koh et al., 1986), because our cultures had very few diaphorase $(+)$ cells.

The inclusion of $100 \mu \mathrm{M} \mathrm{D}$-APV in the 10 -min exposure solution reduced $\mathrm{LDH}$ release to background levels as expected (see Fig. 2A). The neurotoxic effect of $300 \mu \mathrm{M}$ NMDA plus 300 $\mu \mathrm{M}$ glycine was also abolished in a dose-dependent manner by phencyclidine $\left(\mathrm{IC}_{50}, 4.1 \mu \mathrm{M}\right)$ and $\mathrm{Mg}^{2+}\left(\mathrm{IC}_{50}, 7.5 \mathrm{~mm}\right.$; Fig. 1B), 


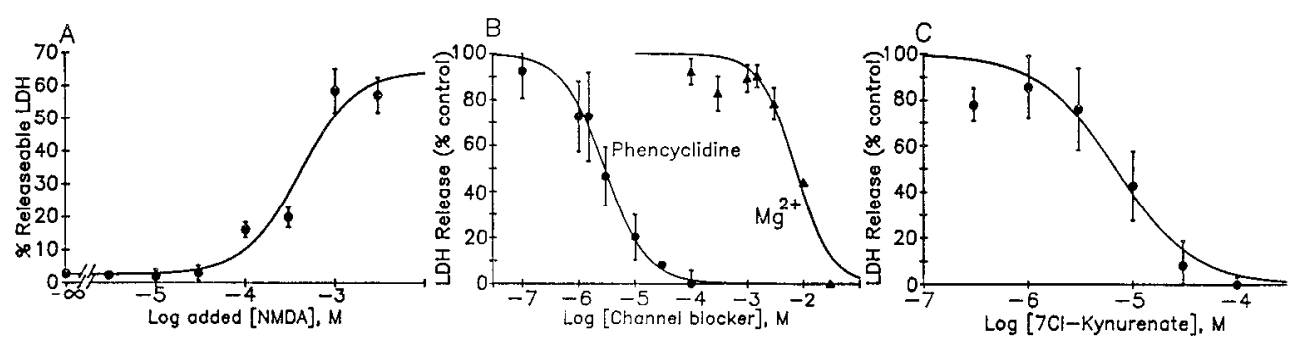

Figure 1. Block of NMDA-induced neurotoxicity. A, Concentration dependence of NMDA-induced neurotoxicity. Exposure of 11-d-old rat cortical neurons for $10 \mathrm{~min}$ to $300 \mu \mathrm{M}$ glycine plus the indicated concentrations of NMDA caused LDH release over the ensuing 18-24 hr. The ordinate plots the amount of LDH released as a percent of the (maximum) amount released by a 1-hr exposure to $300 \mu \mathrm{M}$ NMDA and glycine. The NMDA $\mathrm{EC}_{50}$ was $360 \mu \mathrm{M}(95 \% \mathrm{CI}, 330-400 \mu \mathrm{M} ; n=7)$. The points were fit by a nonlinear least-squares curve-fitting program to a logistic equation: LDH release $=\min +(\max -\min ) /\left[1+\left([\text { agonist }] / \mathrm{EC}_{50}\right)^{n}\right]$, where $\max$ is the response at high agonist concentrations, min is the basal LDH release in absence of added agonist, and $n$ is the Hill slope coefficient. $B$, The NMDA-receptor-channel blockers phencyclidine (circles) and magnesium (triangles) abolished the toxicity incurred by $10-\mathrm{min}$ exposure to $300 \mu \mathrm{M}$ each of NMDA and glycine. The potency of phencyclidine (IC $\mathrm{I}_{50}, 4.1 \mu \mathrm{M}$; $95 \% \mathrm{CI}, 0.70-7.2 \mu \mathrm{M} ; n=5$ ) was much higher than that of magnesium $\left(\mathrm{IC}_{50}, 7.5 \mathrm{~mm} ; 95 \% \mathrm{CI}, 5.2-10.0 \mathrm{~mm} ; n=4\right)$. $C$, Dose-dependent inhibition of NMDA-induced neurotoxicity by 7-chlorokynurenate. Cultures were exposed for $10 \mathrm{~min}$ to $300 \mu \mathrm{M}$ NMDA plus the indicated concentrations of 7-chlorokynurenate, and LDH release was measured 18-24 hr later. The $\mathrm{IC}_{50}$ of 7-chlorokynurenate was $8.6 \mu \mathrm{M}(95 \% \mathrm{CI}, 1.7-17 \mu \mathrm{M} ; n=4)$. In the absence of 7-chlorokynurenate, NMDA caused the release of $23 \pm 4.3 \%$ of the releasable pool of LDH in these experiments. The error bars represent SEM.

or by reducing the calcium concentration from 1.28 to $0.1 \mathrm{mM}$ (D. Mooney, unpublished observations). These results together indicate that the neurotoxic effect of NMDA was due to selective activation of NMDA receptors.

\section{Control by glycine of NMDA-induced neurotoxicity}

In the absence of added glycine, 100 or $300 \mu \mathrm{M}$ NMDA could produce some neurotoxicity, releasing $18.3 \pm 1.2 \%$ of the releasable pool of LDH $(n=58)$. The competitive antagonist at the glycine recognition site of the NMDA receptor, 7-chlorokynurenic acid, could abolish NMDA neurotoxicity. The $\mathrm{IC}_{50}$ for 7-chlorokynurenate block of NMDA excitotoxicity in the absence of added glycine was $8.6 \mu \mathrm{M}(95 \% \mathrm{CI}, 1.7-17.1 \mu \mathrm{M} ; n$ $=4$; Fig. $1 \mathrm{C}$ ). Because glycine and 7-chlorokynurenate have approximately equal affinities for the glycine recognition site (Kemp et al., 1988; Kleckner and Dingledine, 1989), this finding is consistent with the presence of about $9 \mu \mathrm{M}$ glycine in the medium above the layer of cultured cells. High-performance liquid chromatography (HPLC) analysis of the medium exposed to cultured cells revealed about $6 \mu \mathrm{M}$ glycine in the medium. The higher estimate for residual glycine concentration from the 7-chlorokynurenate $\mathrm{IC}_{50}$ is likely to be due to a higher glycine concentration near the cell layer rather than in the bulk solution sampled for HPLC measurement.

In the presence of $30 \mu \mathrm{M} 7$-chlorokynurenic acid, the neurotoxic effect of $300 \mu \mathrm{M}$ NMDA could be restored by addition of glycine (Fig. $2 B$ ) or several glycine analogs that are selective agonists at the glycine recognition site of the NMDA receptor. These include D-serine, ACC, D-alanine, and $\beta$-fluoro-D-alanine. The relative potencies and relative efficacies of these 5 agonists were similar to those described in electrophysiological studies of the glycine recognition site expressed in frog oocytes (Table 1 ). The cyclic analog ACC was the most potent, yet least efficacious, agonist in both electrophysiological and neurotoxicity assays.

\section{Modulation by glycine of NMDA-induced neurotoxicity}

In 58 of 71 experiments, the addition of glycine to the NMDA exposure solution resulted in at least $20 \%$ greater cell death than for cultures incubated with NMDA alone. The $\mathrm{EC}_{50}$ of glycine for potentiating the neurotoxic effect of NMDA was $27 \mu \mathrm{M}(95 \%$
CI, 15-31 $\mu \mathrm{M} ; n=13)$. Glycine alone (1 $\mathrm{mm})$ was ineffective. The maximum effect of glycine was to double the neurotoxic effect of NMDA (Fig. $2 A$ ). The $\mathrm{EC}_{50}$ of glycine in potentiating the neurotoxic effect of NMDA $(27 \mu \mathrm{M})$ is $50-100$-fold higher than that required to permit NMDA-induced cationic currents in patch-clamped isolated neurons (Johnson and Ascher, 1987; Lester et al., 1989) or voltage-clamped frog oocytes (Kleckner and Dingledine, 1988; Kushner et al., 1988; McBain et al., 1989), which raises the question of which receptor glycine is acting through.

Several findings indicate that the potentiating effect of glycine is not due to its action on the glycine recognition site of the NMDA receptor, but rather, to activation of the strychninesensitive "inhibitory" glycine receptor. First, $30 \mu \mathrm{M}$ 7-chlorokynurenic acid (100 times its $K_{B}$ for the glycine site on the NMDA receptor in electrophysiological or receptor binding assays) shifted the glycine dose-response curve only about 5-fold to the right (Fig. $2 B$ ). Second, selective agonists at the glycine site on NMDA receptors wcre unablc to substitute for glycine in the absence of 7-chlorokynurenic acid, presumably because this site was already saturated by endogenous glycine. An example of robust potentiation by glycine but not $D$-serine is shown in Figure 3. Several other strong agonists at this glycine site, including ACC (300 $\mu \mathrm{M}, n=4)$, D-alanine (300 $\mu \mathrm{M}, n=11)$, and $\beta$-fluoro-D-alanine ( $300 \mu \mathrm{M}, n=5$ ), were also unable to potentiate NMDA-induced neurotoxicity in the absence of 7-chlorokynurenic acid. These analogs are not likely to be partial glycine agonists in this assay because they did not reduce the excitotoxic effect of NMDA alone (e.g., Fig. 3), which depends on a low ambient glycine concentration (see above). Second, both $\beta$-alanine and taurine, which are selective agonists at the strychnine-sensitive glycine receptor (e.g., Tokutomi et al., 1989), could potentiate NMDA excitotoxicity (Fig. 4). Finally, strychnine could reduce the potentiating effect of $1 \mathrm{~mm}$ glycine (Fig. 5). The block by strychnine may have occurred in 2 phases, the higher affinity component $\left(\mathrm{IC}_{50}, 550 \mathrm{nM} ; 95 \% \mathrm{CI}, 91-940 \mathrm{nM}\right.$; $n=6$ ), apparently due to a selective removal of the glycinepotentiated component of neurotoxicity, plus a lower affinity action (at $30 \mu \mathrm{M}$ ), possibly due to a direct block of the NMDA ion channel (Bertolino and Vicini, 1988).

These results raise the possibility that the influx of chloride 


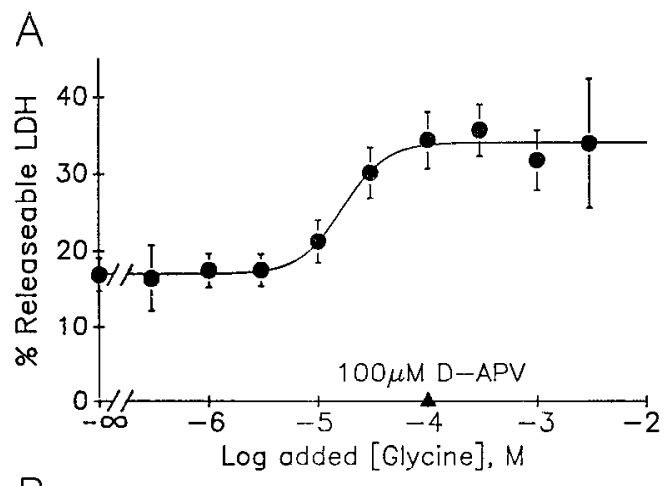

B

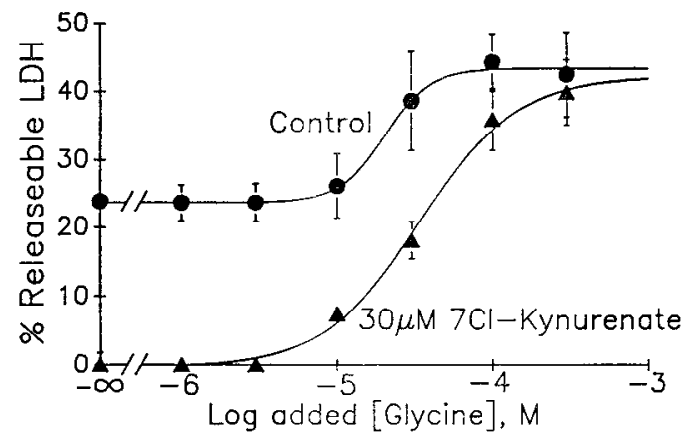

Figure 2. Low potency of glycine in potentiation of NMDA-induced neurotoxicity. $A$, Glycine increased NMDA neurotoxicity in a concentration-dependent manner. Cultures were exposed to 100 or $300 \mu \mathrm{M}$ NMDA for $10 \mathrm{~min}$ in the presence of the indicated concentrations of glycine. The $\mathrm{EC}_{50}$ of glycine was $27 \mu \mathrm{M}(95 \% \mathrm{CI}, 15-31 \mu \mathrm{M} ; n=13)$. The NMDA-receptor antagonist D-APV $(100 \mu \mathrm{M}$; triangle $)$ abolished the injury caused by $100 \mu \mathrm{M}$ glycine and 100 or $300 \mu \mathrm{M}$ NMDA $(n=$ 13). $B$, Dose-response curves for glycine with and without 7-chlorokynurenate. Cultures were incubated in $300 \mu \mathrm{M}$ NMDA plus the indicated concentrations of glycine with (triangles) and without (circles) 30 $\mu \mathrm{M}$ 7-chlorokynurenate ( $n=4$ experiments). The $\mathrm{EC}_{50}$ of glycine was $20 \mu \mathrm{M}$ in the absence of 7-chlorokynurenate and $30 \mu \mathrm{M}$ in the presence of 7-chlorokynurenate. Under the assumption that glycine is required for NMDA neurotoxicity, 7-chlorokynurenate shifted the glycine response about 5 -fold along the $x$-axis. The error bars represent SEM.

through strychnine-sensitive receptors could be responsible for the observed potentiating effect of glycine. This hypothesis was supported by 2 additional findings. First, GABA ( $1 \mathrm{~mm})$ could also potentiate the neurotoxic effect of NMDA. In 2 of 3 ex-

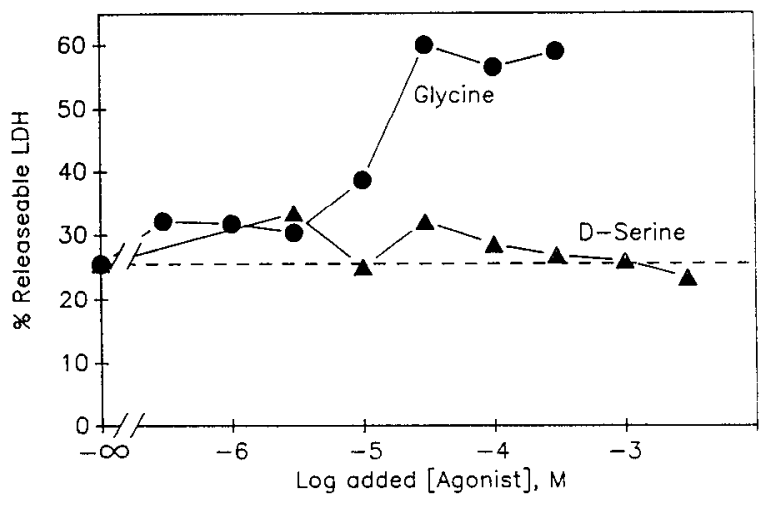

Figure 3. D-Serine alone has no effect on NMDA neurotoxicity. A typical experiment $(n=10)$ wherein increasing concentrations of glycine (circles) produced a significant increase of neurotoxicity induced by 100 $\mu \mathrm{M}$ NMDA, but D-serine (triangles) had no effect. The dashed line represents the LDH release caused by $100 \mu \mathrm{M}$ NMDA in the absence of glycine or D-serine.

pcriments, both GABA and glycine potentiated cell injury caused by NMDA; in the third experiment, neither amino acid was effective. Second, reduction of the bath chloride concentration from 145 to $48 \mathrm{~mm}$ by replacement with methanesulfonate, a procedure that should limit chloride entry through glycine-activated receptor channels, eliminated the potentiating effects of glycine (Fig. 6). Chloride replacement also reduced the neurotoxic effect of NMDA alone, presumably by limiting the initial cell swelling that contributes to damage (Rothman, 1985; Choi, 1987).

\section{Discussion}

The results provide evidence for 2 distinct roles of glycine in the neurotoxic action of NMDA. First, a requirement for glycine is suggested because 7-chlorokynurenic acid, a competitive blocker of this glycine site (Kemp et al., 1988; Kleckner and Dingledine, 1989), could abolish the ncurotoxic cffect of NMDA. The potency of 7-chlorokynurenic acid $\left(\mathrm{IC}_{50}, 8.6 \mu \mathrm{M}\right)$ is predicted from the measured levels of glycine in our culture medium, but the concentration required for complete protection $(30 \mu \mathrm{M})$ is in the range at which some reduction of AMPA-receptor activation may also occur (Kleckner and Dingledine, 1989). In the presence of enough 7-chlorokynurenic acid to displace all en-

Table 1. Comparison of glycine analogs as potentiators of NMDA-induced neurotoxicity in cell culture and ionic currents in oocytes

\begin{tabular}{|c|c|c|c|c|c|c|c|}
\hline \multirow[b]{2}{*}{ Analog } & \multicolumn{3}{|c|}{$\underline{E C_{50}}$} & \multicolumn{2}{|c|}{$\underline{\text { Relative potency }}$} & \multicolumn{2}{|c|}{$\underline{\text { Relative efficacy }}$} \\
\hline & $\mu \mathrm{M}$ & $\begin{array}{l}95 \% \mathrm{Cl} \\
(\mu \mathrm{M})\end{array}$ & $n$ & $\begin{array}{l}\text { Tox- } \\
\text { icity }^{a}\end{array}$ & $\begin{array}{l}\text { Oo- } \\
\text { cytes }^{b}\end{array}$ & $\begin{array}{l}\text { Tox- } \\
\text { icity }^{a}\end{array}$ & $\begin{array}{l}\text { Oo- } \\
\text { cytes }^{b}\end{array}$ \\
\hline $\mathrm{ACC}$ & 9 & $7.8-11$ & 6 & 2.90 & 1.93 & $0.57 \pm 0.08$ & 0.89 \\
\hline Glycine & 27 & $22-31$ & 10 & 1 & 1 & 1 & 1 \\
\hline D-Serine & 47 & $20-66$ & 7 & 0.57 & 0.62 & $0.93 \pm 0.08$ & 0.95 \\
\hline D-Alanine & 67 & $19-115$ & 6 & 0.40 & 0.34 & $0.85 \pm 0.18$ & 0.85 \\
\hline$\beta$-Fluoro-D-alanine & 97 & $82-111$ & 7 & 0.28 & 0.35 & $0.65 \pm 0.11$ & 0.76 \\
\hline
\end{tabular}

a Neurotoxicity was evaluated by the amount of IDH released from cultures exposed for 10 min to $300 \mu \mathrm{M}$ NMDA plus 6 concentrations of each glycine analog. 7-Chlorokynurenate $(30 \mu \mathrm{M})$ was present in all experiments to eliminate the effect of the basal level of glycine present in the culture media. Dose-response curves were fit by a logistic equation, from which the $\mathrm{EC}_{50}$ and efficacy (relative to that of glycine determined in the same experiments) were calculated.

${ }^{b}$ Data were taken from McBain et al. (1989), in which the ability of glycine analog to permit NMDA-evoked ionic current in voltage-clamped Xenopus oocytes was determined. 


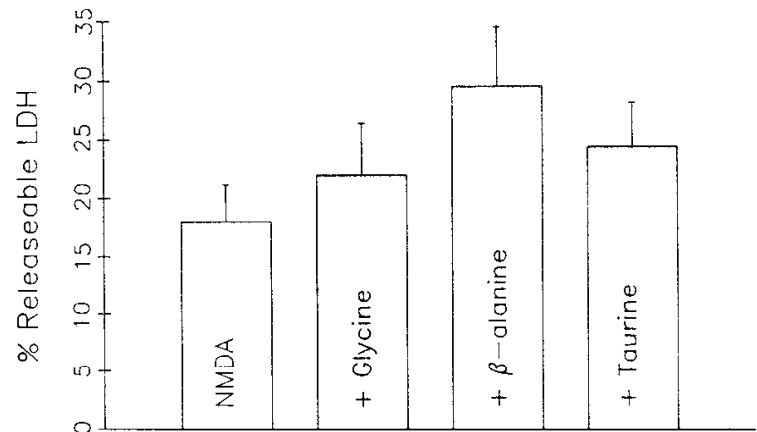

Figure 4. Potentiation of NMDA neurotoxicity by agonists of inhibitory glycine receptor. Cortical neurons were exposed to $300 \mu \mathrm{M}$ NMDA alone and with $1 \mathrm{~mm}$ glycine, $\beta$-alanine, or taurine. In 7 experiments, these agonists increased the injury caused by NMDA exposure with the relative effectiveness: $\beta$-alanine $>$ taurine $>$ glycine. As with glycine, neither $\beta$-alaninc nor taurinc causcd any injury when exposed to neurons in the absence of NMDA. In these 7 experiments, the $22 \%$ mean potentiation by glycine did not reach statistical significance. The effects of $\beta$-alanine $(P<0.01)$ and taurine $(P<0.02)$ were, however, significantly different from that of NMDA alone. The error bars represent SEM.

dogenous glycine from its recognition site on the NMDA receptor $(30 \mu \mathrm{M}), 5$ selective agonists at this site were able to restore the neurotoxic effect of NMDA, and their relative potency and efficacy were as previously reported in electrophysiological (McBain et al., 1989) and receptor binding (Snell et al., 1988; Marvizon et al., 1989) studies of the glycine site on NMDA receptors. Thus, in agreement with Patel et al. (1990), our data would support a permissive role for glycine in the neurotoxic action of NMDA on cortical neurons.

A component of ischemic forebrain damage in the gerbil and rat can be prevented by competitive (Simon et al., 1984) and uncompetitive (e.g., Gill et al., 1987) blockers of the NMDA receptor. Whether glycine-site blockade is also protective in intact animals is not known. The present results, and those of Patel et al. (1990) and Shalaby et al. (1989), indicate that glycinesite blockade can provide complete protection of cortical neu-

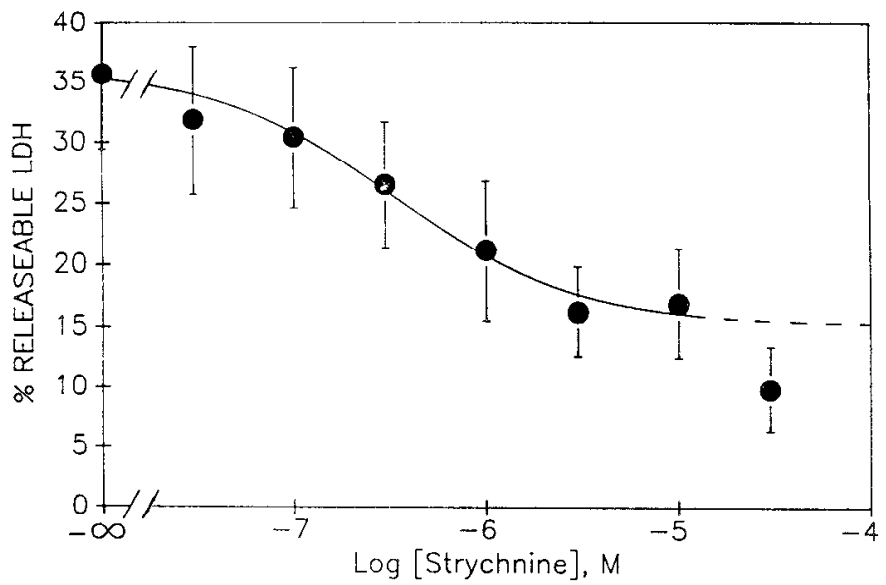

Figure 5. Strychnine dose-dependently reduced injury caused by 10 min exposure to $300 \mu \mathrm{M}$ NMDA and $1 \mathrm{~mm}$ glycine. This effect was apparently biphasic, with an $\mathbf{I C}_{50}$ for the higher affinity component of $550 \mathrm{~nm}(95 \% \mathrm{CI}, 91-940 \mathrm{nM} ; n=6)$. This phase is presumably an action on the classical glycine receptor. Additional block by $30 \mu \mathrm{M}$ strychnine may reflect voltage-dependent channel block reported by Bertolino and Vicini (1988). The error bars represent SEM.

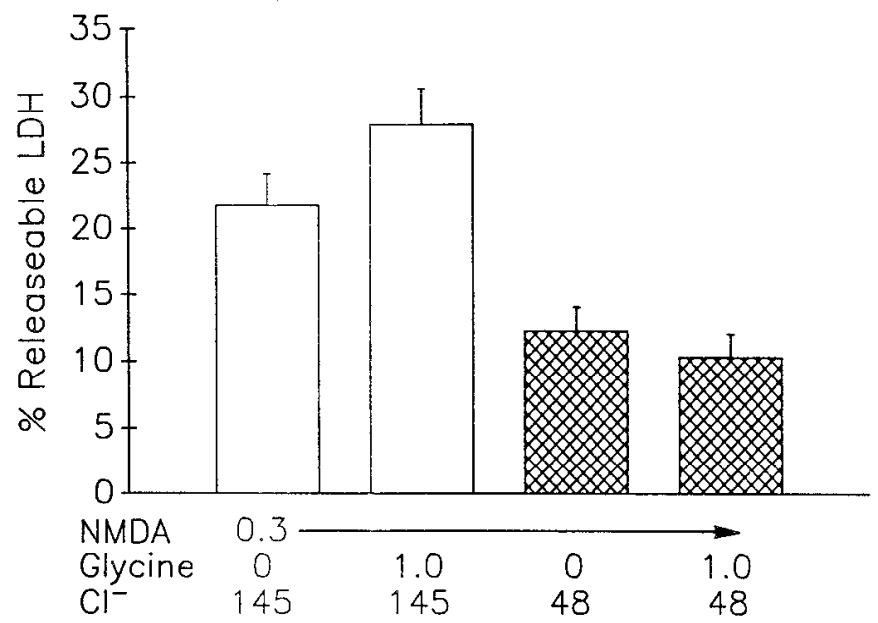

Figure 6. Effect of decreased chloride concentration on neurotoxicity. Glycine (1 $\mathrm{mm}$ ) increased the LDH released by a 10 -min exposure to $300 \mu \mathrm{M}$ NMDA from $22 \%$ to $28 \%$ of maximum release (open columns; $P<0.05, n=6$ ). Replacement of $97 \mathrm{~mm}$ of chloride with methanesulfonate, however, eliminated the ability of $1 \mathrm{~mm}$ glycine to potentiate NMDA-induced neurotoxicity (hatched columns; $n=6$ ). LDH release is plotted as a percent of the NMDA-releasable pool in $145 \mathrm{~mm}$ chloride. The error hars represent SEM.

rons in culture from the excitotoxic effects of NMDA-receptor activation. The in vivo efficacy as anti-ischemic agents of drugs targeted to the glycine recognition site will, however, depend on how high the ambient glycine concentration is in the ischemic area.

The second role of glycine appears indirect, not mediated by its recognition site on the NMDA receptor. Glycine itself potentiated the neurotoxic effect of NMDA, but in this case, via the strychnine-sensitive "inhibitory" glycine receptor. The required concentration of glycine was 50-100-fold higher than that required to activate the NMDA receptor, though similar to that acting on the classical glycine receptor (Tokutomi et al., 1989). The potentiating effects of much lower glycine concentrations reported by Finkbeiner and Stevens (1988) and Patel et al. (1990) are presumably due to an ambient glycine level in their cultures that is subsaturating for the NMDA receptor. Two selective agonists of the strychnine-sensitive receptor, $\beta$-alanine and taurine, also potentiated the neurotoxic action of NMDA, and the cffect of glycinc was blocked by strychnine. Although strychnine binding sites are very sparse in the adult rat cortex (Bristow et al., 1986), other evidence suggests that the neurons in our cultures should express some classical glycine receptors. Akagi and Miledi (1988) showed that mRNA encoding inhibitory glycine receptors could be isolated from the adult rat cortex, and Dichter (1980) reported that strychnine-sensitive conductance increases could be evoked by glycine applied to rat cortical neurons in culture.

Because the neurotoxic effect of NMDA could also be potentiated by GABA, and the potentiation by glycine could be eliminated by reducing the chloride gradient across the neuron membrane, we suggest that loading neurons with $\mathrm{Cl}^{-}$is the key event in this modulatory action of the inhibitory amino acids. It is thought that the rise in $[\mathrm{Ca}]_{i}$ caused by massive NMDA-receptor activation mediates much of the ensuing neuron injury (Choi, 1987; Manev et al., 1989; but see Rothman, 1985; Olney et al., 1986). Moreover, NMDA-mediated neurotoxicity is greater at 
room temperature than at $37^{\circ} \mathrm{C}$ (Favaron et al., 1988), possibly due to a slower or less effective clearance of $[\mathrm{Ca}]_{i}$ at the lower temperature. We suggest that the extra metabolic burden of transporting $\mathrm{Cl}^{-}$to reestablish a normal $\mathrm{Cl}^{-}$gradient may divert energy supplies that would otherwise be used to pump $\mathrm{Ca}^{2+}$ out of the cytoplasm. The reduction of energy stores by hypoglycemia also enhances the neurotoxic effect of NMDA-receptor activation (Novelli et al., 1988).

Thus, the activation of inhibitory amino acid receptors would have 2 opposing actions on neurotoxicity mediated by NMDA receptors: a protective effect of hyperpolarization that enhances voltage-dependent $\mathrm{Mg}^{2+}$ block (Mayer et al., 1984; Nowak et al., 1984) and if NMDA receptors break through the $\mathrm{Mg}^{2+}$ block, a metabolic depletion of energy reserves that exacerbates neurotoxicity. Alternative explanations for potentiation by glycine would involve intracellular $\mathrm{pH}$ imbalance due to disruption of $\mathrm{Cl}$-bicarbonate exchange, or a direct effect of neuronal swelling accompanying $\mathrm{Cl}^{-}$loading.

Although the block of NMDA-evoked neurotoxicity by D-APV, 7-chlorokynurenic acid, phencyclidine, and low [Ca] argues that this action is mediated by NMDA receptors, the low potency of both NMDA $\left(\mathrm{EC}_{50}, 364 \mu \mathrm{M}\right)$ and $\mathrm{Mg}^{2+}\left(\mathrm{IC}_{50}, 7.5 \mathrm{mM}\right)$ in this assay deserves comment. The low potency of NMDA may be due to the inclusion of D-APV in the postincubation culture media and the use of an incubation temperature of $37^{\circ} \mathrm{C}$ rather than room tcmpcraturc, bccause the higher tempcrature is reported to cause a 50 -fold increase in the glutamate $\mathrm{LD}_{50}$ in cerebellar or cortical cultures (Favaron et al., 1988). Another contributing factor may have been a high proportion of GABAergic neurons in our cultures (cf. Hoch and Dingledine, 1986), which are known to be much less sensitive to the neurotoxic effect of NMDA (Tecoma and Choi, 1989).

The potency of $\mathrm{Mg}^{21}$ is that predicted (Ascher and Nowak, 1988; Kleckner and Dingledine, 1990) for neurons depolarized to near $0 \mathrm{mV}$ by NMDA, because the potency of this blocker is voltage dependent. The reason for the higher potency of phencyclidine is less clear. The great difference in half-time for dissociation from open NMDA channels of $\mathrm{Mg}^{2+}$ (2-3 msec; Mayer and Westbrook, 1985) and phencyclidine or its analogs (several min; Kloog et al., 1988; see also MacDonald et al., 1987; Kushner et al., 1988) probably accounts for the difference in potency of the 2 blockers observed over a 5-10-min incubation period (Fig. 1B).

In sum, evidence for 2 distinct effects of glycine on NMDAinduced neurotoxicity was produced: a direct permissive action on the NMDA receptor itself and a modulatory, presumably metabolic, effect (shared by other inhibitory amino acids) mediated by $\mathrm{Cl}^{-}$loading of the neurons. The indirect potentiation by inhibitory amino acids of NMDA-receptor-mediated neurotoxicity is unexpected and underscores the complexity of the control of NMDA-receptor activation hy cortical neurons.

\section{References}

Akagi H, Miledi R (1988) Heterogeneity of glycine receptors and their messenger RNAs in rat brain and spinal cord. Science 242:270-273.

Ascher P, Nowak L (1988) The role of divalent cations in the $N$-methyl-D-aspartate responses of mouse central neurones in culture. J Physiol (Lond) 399:247-266.

Benveniste M, Clements J, Vyklicky L, Mayer ML (1990) A kinetic analysis of the modulation of $N$-methyl-D-aspartic acid receptors by glycine in mouse cultured hippocampal neurones. J Physiol (Lond), in press.

Bertolino M, Vicini S (1988) Voltage-dependent block by strychnine of $N$-methyl-D-aspartic acid activated cationic channels in rat cortical neurons in culture. Mol Pharmacol 34:98-103.

Bristow DR, Bowery NG, Woodruff GN (1986) Light microscopic autoradiographic localization of $\left[{ }^{3} \mathrm{H}\right]$ glycine and $\left[{ }^{3} \mathrm{H}\right]$ strychnine binding sites in rat brain. Eur J Pharmacol 126:303-307.

Choi DW (1987) Ionic dependence of glutamate neurotoxicity. J Neurosci 7:369-379.

Choi DW, Maulucci-Gedde M, Kriegstein AR (1987) Glutamate neurotoxicity in cortical cell culture. J Neurosci 7:357-368.

Choi DW, Koh J, Peters S (1988) Pharmacology of glutamate neurotoxicity in cortical cell culture: attenuation by NMDA antagonists. J Neurosci 8:185-196.

Dichter M (1980) Physiological identification of GABA as the inhibitory transmitter for mammalian neurons in cell culture. Brain Res 190:111-121.

Favaron M, Manev H, Alho H, Bertilino M, Ferret B, Guidotti A, Costa E (1988) Gangliosides prevent glutamate and kainate neurotoxicity in primary neuronal cultures of neonatal rat cerebellum and cortex. Proc Natl Acad Sci USA 85:7351-7355.

Finkbeiner S, Stevens CF (1988) Applications of quantitative measurements for assessing glutamate neurotoxicity. Proc Natl Acad Sci USA 85:4071-4074.

Fransden A, Schousboe A (1987) Time and concentration dependency of the toxicity of excitatory amino acids on cerebral neurones in primary culture. Neurochem Int 10:583-591.

Gill R, Foster AC, Woodruff GN (1987) Systematic administration of MK-801 protects against ischemia-induced hippocampal neurodegeneration in the gerbil. J Neurosci 7:3343-3349.

Goldberg MP, Weiss JH, Pham P-C, Choi DW (1987) $N$-methyl$D$-aspartate receptors mediate hypoxic neuronal injury in cortical culture. J Pharmacol Exp Ther 243:784-791.

Hartley DM, Choi DW (1989) Delayed rescue of $N$-methyl-D-aspartate-mediated neuronal injury in cortical culture. J Pharmacol Exp Ther 250:752-758.

Hoch DB, Dingledine R (1986) GABAergic neurons in rat hippocampal culture. Dev Brain Res 25:53-64.

Huettner JE (1989) Indole-2-carboxylic acid: a competitive antagonist of potentiation by glycine at the NMDA receptor. Science 243:16111613.

Johnson JW, Ascher P (1987) Glycine potentiates the NMDA response in cultured mouse brain neurones. Nature 325:529-531.

Kemp JA, Foster AC, Leeson PD, Priestley T, Tridgett R, Iversen LL, Woodruff GN (1988) 7-Chlorokynurenic acid is a selective antagonist at the glycine modulatory site of the $N$-methyl-D-aspartate receptor complex. Proc Natl Acad Sci USA 85:6547-6550.

Kleckner NW, Dingledine R (1988) Requirement for glycine in activation of NMDA receptors expressed in Xenopus oocytes. Science 241:835-837.

Kleckner NW, Dingledine R (1989) Selectivity of quinoxalines and kynurenines as antagonists of the glycine site on NMDA receptors in Xenopus oocytes. Mol Pharmacol 36:430-436.

Kleckner NW, Dingledine R (1990) Developmental regulation of NMDA receptors by magnesium and glycine. Soc Neurosci Abstr 16: 619.

Kloog Y, Haring R, Sokolovsky M (1988) Kinetic characterization of the phencyclidine- $N$-methyl-D-aspartate receptor interaction: evidence for a steric blockade of the channel. Biochemistry 27:843-848.

Koh J-Y, Choi DW (1987) Quantitative determination of glutamate mediated cortical neuronal injury in cell culture by lactate dehydrogenase efflux assay. J Neurosci Meth 20:83-90.

Koh J-Y, Peters S, Choi DW (1986) Neurons containing NADPHdiaphorase are selectively resistant to quinolinate toxicity. Science 234:73-76.

Kushner L, Lerma J, Zukin RS, Bennett MVL (1988) Co-expression of $N$-methyl-D-aspartate and phencyclidine receptors in Xenopus oocytes injected with rat brain mRNA. Proc Natl Acad Sci USA 85: 3250-3254.

Lester RJ, Quarum ML, Parker JD, Weber E, Jahr CE (1989) Interaction of 6-cyano-7-nitroquinoxaline-2,3-dione (CNQX) with the $N$-methyl-D-aspartate (NMDA) receptor-associated glycine binding site. Mol Pharmacol 35:565-570.

MacDonald JF, Miljkovic Z, Pennefather P (1987) Use-dependent block of excitatory amino acid currents in cultured neurons by ketamine. J Neurophysiol 58:251-266.

Manev H, Favaron M, Guidotti A, Costa E (1989) Delayed increase 
of $\mathrm{Ca}^{+2}$ influx elicited by glutamate: role in neuronal death. Mol Pharmacol 36:106-112.

Martin JB, Gusella JF (1986) Huntington's disease: pathogenesis and management. N Engl J Med 315:1267-1272.

Marvizon JCG, Lewin AH, Skolnick P (1989) 1-Aminocyclopropanecarboxylic acid: a potent and selective ligand for the glycine modulatory site of the $N$-methyl-D-aspartate receptor complex. J Neurochem 52:992-994.

Mayer ML, Westbrook GL (1985) The action of $N$-methyl-D-aspartic acid on mouse spinal neurones in culture. J Physiol (Lond) 361:6590.

Mayer ML, Westbrook GL, Guthrie PB (1984) Voltage-dependent block by $\mathrm{Mg}^{+2}$ of NMDA responses in spinal cord neurones. Nature 309:263-265.

McBain CJ, Kleckner NW, Wyrick S, Dingledine R (1989) Structural requirements for activation of the glycine coagonist site of $N$-methylD-aspartate receptors expressed in Xenopus oocytes. Mol Pharmacol 36:556-565.

McNamara D, Dingledine R (1988) Potentiation by glycine of $N$-methyl-D-aspartate induced excitotoxicity in rat cortical cell culture. Soc Neurosci Abstr 14:236.

McNamara D, Dingledine R (1989) Requirement for glycine in NMDAinduced excitotoxicity in rat cortical cultures. Soc Neurosci Abstr 15: 481.

Moroni F, Lombardi G, Moneti G, Aldino C (1984) The excitotoxin quinolinic acid is present in the brain of several mammals and its cortical content increases during the aging process. Neurosci Lett 47: $51-55$.

Novelli A, Reilly AJ, Lysko PG, Henneberry RC (1988) Glutamate becomes neurotoxic via the $N$-methyl-D-aspartate receptor when intracellular energy stores are reduced. Brain Res 451:205-212.

Nowak L, Bregestovski P, Ascher P, Herbet A, Prochiantz A (1984)
Magncsium gates glutamate-activated channels in mouse central neurones. Nature 309:462-465.

Olney JW, Price MT, Samson L, LaBruyere J (1986) The role of specific ions in glutamate neurotoxicity. Neurosci Lett 65:65-71.

Ozyurt E, Graham DI, Woodruff GN, McCulloch J (1988) Protective effect of the glutamate antagonist, MK-801 in focal cerebral ischemia in the cat. J Cerebral Blood Flow Metab 8:138-143.

Patel J, Zinkand WC, Thompson C, Keith R, Salama A (1990) Role of glycine in the $N$-methyl-D-aspartate-mediated neuronal cytotoxicity. J Neurochem 54:849-854.

Rothman SM (1983) Synaptic activity mediates death of hypoxic neurons. Science 220:536-537.

Rothman SM (1985) The neurotoxicity of excitatory amino acids is produced by passive chloride influx. J Neurosci 5:1483-1489.

Rothman SM, Thurston JH, Hauhart RE, Clark GD, Solomon JS (1987) Ketamine protects hippocampal neurons from anoxia in vitro. Neuroscience 21:673-678.

Shalaby I, Chenard B, Prochniak M (1989) Glycine reverses 7-chlorokynurenate blockade of glutamate neurotoxicity in cell culture. Eur J Pharmacol 160:309-311.

Siejö BK, Weiloch T (1986) Epileptic brain damage: pathophysiology and neurochemical pathology. Adv Neurol 44:813-829.

Simon RP, Swan JH, Griffiths T, Meldrum BS (1984) Blockade of $N$-methyl-D-aspartate receptors may protect against ischemic damage in the brain. Science 226:850-852.

Snell LD, Morter RS, Johnson KM (1988) Structural requirements for activation of the glycine receptor that modulates the $N$-methylD-aspartate operated ion channel. Eur J Pharmacol 156:105-110.

Tecoma ES, Choi DW (1989) GABAcrgic ncocortical ncurons are resistant to NMDA receptor-mediated injury. Neurology 39:676-682.

Tokutomi N, Kaneda M, Akaike N (1989) What confers specificity on glycine for its receptor site? Br J Pharmacol 97:353-360. 